\title{
The Rise and Fall of the Boeotians: Polybius $20.4-7$ as a Literary Topos
}

\author{
Christel Müller
}

\section{INTRODUCTION}

M. Feyel's work on Boeotia, Polybe et l'histoire de Béotie au IIIe siècle avant notre ère, published in 1942, was based above all, as its title suggests, on an analysis of Polybius' work, and in particular on the part of Book $20^{1}$ where the Achaean historian offers his reader a tableau of the situation in Boeotia between c.250 and 200 BC. Book 20, which has survived only in fragments, was devoted to the arrival in Greece of king Antiochus III. The sections that concern us appear in the first year of the 147th Olympiad, 192/91 вс, ${ }^{2}$ at the very moment when Antiochus reaches the gates of Thebes after staying at Chalcis. To summarize, we can say that Polybius offers, in an especially unfavourable light, an account of a series of events from 245 вс (the Boeotarchy of Abaeocritus) to 192 (the alliance of the Boeotians with Antiochus). The primary function of this passage in Polybius' account is clear: to look back to Boeotia's past for an explanation for such an inexplicable action. ${ }^{3}$ This passage from Book 20 is, however, almost unique: few Greek states in Polybius are given such a complete and detailed account of their decadence. Modern commentators have never really considered it totally trustworthy, decadence of course being a rather suspect concept; but this has not stopped them from taking some elements literally, while thinking that Polybius has simply

${ }^{1}$ Plb. 20. 4-7. This passage has been commented upon by various scholars: Feyel 1942; Cloché 1952: 240-9; Aymard 1946 (in a review of Feyel 1942); Roesch 1965: 112-21 (on the federal Strategos); Roussel 1970, ad. loc.; Mendels 1977: 161-5 (on Philip V as demagogue); Mendels 1978: 29-30 (on Antiochus III as demagogue); Étienne and Knoepfler 1976: 331-7 (the entry of Opus in the Boeotian Confederacy and the incident at Larymna); Walbank, HCP iii. 6674; Roesch 1982: 404-11 (justice in Boeotia and in particular foreign judges).

${ }^{2}$ For the counting by Olympiads, cf. Walbank, HCP iii. 56.

${ }^{3}$ Feyel 1942: 13-14. 
exaggerated. With some degree of distrust, commentators have accordingly adopted this passage in their own way, fitting it into their preoccupations concerning the period. Only the chronology of this account of decadence has been subject to debate.

A couple of specific examples are worth revisiting. The first is Feyel, who, although he makes an effort to 'control' (in his terms) Polybius' viewpoint, fails to eliminate the idea of decadence. Not wanting to give too much credit to Polybius' assessment, Feyel dates the start of Boeotia's decline only to the 220s, ${ }^{4}$ and not from 245, when Abaeocritus was a leader. But after 220 he falls in line with the Polybian ideology on which his analysis depends, especially in terms of Boeotia's internal politics. In the conclusion to his chapter on political life, Feyel offers a pessimistic view of Boeotia based on Polybius. At the same time he denounces both the internal situation in France and Germany at the end of the 1930s and Philip V, the Macedonian king, is 'a complicated soul capable of cruelty' who 'for the pleasure of inflicting harm' comes and 'destroys the social order of his neighbours'. Feyel's target is as much Hitler as it is Philip V. ${ }^{5}$ The second example, M. Rostovtzeff, is even more of a caricature. ${ }^{6}$ For him, the theme of decadence evokes all the political problems of Russia at the start of the twentieth century: he uses a vocabulary that is characteristically Marxist and bourgeois at the same time. One fragment of Polybius therefore shows how 'the class struggle reaches its culmination in Boeotia at this time. The mob ruled. They were represented by generals whose decisions were determined by their desire to please the proletariat.'

My paper offers a completely different angle on this passage from those of previous commentators. I shall demonstrate that the passage, in so far as it is a digression on decadence, is more a literary construct than anything else. Its different elements can be found in what I shall refer to as the 'vertical intertext', namely the whole of Greek literature before Polybius; and the 'horizontal intertext', or the 'intratext', 7 namely the text of Polybius' Histories,

\footnotetext{
4 The date is not supported by Aymard 1946, who considers that there is virtually no difference between the situation before and after what he regards as a false watershed: on the ground that the inscriptions offer few tangible indications of change, Aymard 1946: 313 argues that 'le contraste entre les années qui précèdent et celles qui suivent 220 demeure insuffisamment établi. Bien plutôt, les choses ne devaient pas aller très brillamment avant 220 et elles n'ont pas tourné brusquement à la catastrophe'. So what influenced Feyel in his choice of 220 as this pivotal date? Is it not in fact Polybius' own text that suggested it? For this is the year when Book 3 starts, the first real year of his Histories: the previous two books serve in fact as prolegomena to the work as a whole (cf. Beck, ch. 6 in this volume). On the beginning of the Histories, cf. Walbank 1972a: 16.

${ }_{5}$ The supposed demagogic intervention in central Greece has been dismissed by Mendels 1977: 163: 'It is rather difficult to find evidence for an active demagogic role played by Philip in Boeotia.'

${ }^{6}$ Rostovtzeff 1941: 611-12.

7 On intratextuality, see e.g. Sharrock and Morales 2000. As a general point, it is notable that concepts such as intertextuality are less theorized on the Greek side than on the Roman one (see
} 
which itself offers keys to understanding, through the reading of similar digressions. My thesis is as follows:

(a) First, that the passage is nothing but a motif, in the rhetorical or aesthetic sense of the term, a Leitmotiv, and is understood better in narrative rather than historical terms.

(b) Secondly, that, contrary to Polybius' assertion on the importation of Greek decadence into Rome after the Third Macedonian War, the matrix on which the Leitmotiv is constructed is Roman and not Greek.

My paper will consider three elements: the text, the context, and the intertext. Or, in more elaborate terms, an internal critique to show the passage's incoherences, an external critique, i.e. a historical analysis to demonstrate the inappropriate assessment offered by the passage; and finally an analysis of the intertext or the different layers of the intertext.

\section{INTERNAL CRITIQUE AND THE PROBLEMS OF THE TEXT'S POSITION IN THE NARRATIVE}

If Polybius' aim is clear, to explain the absurd behaviour of the Boeotians, then the inclusion of the passage in the narrative train is less obvious. Feyel had already raised the questions without being able to offer an answer: 'why has Polybius inserted this lengthy disposition at the moment when he describes the arrival of Antiochus at Thebes, an event of little consequence for Boeotia, as he himself recognizes at the end of the digression (20.7), instead of holding it back for the book where he has to narrate the catastrophes of 172 or those of $146 ?^{8}$ In fact the digression finds no natural place either in the course of the events or in the narrative. The disjunction is clear between paragraphs 3 and 4: Polybius makes no transition between the support given by Antiochus to the Epirotes and the Eleans and the decadence of Boeotia, the description of which begins abruptly with 'The Boeotians, already for a long time...'. One could, of course, fall back on the fragmentary nature of Book 20 and suggest that the passage has not survived intact. However, the order followed by Livy, ${ }^{9}$ who condenses Polybius, shows that no gap between 20. 3 and 20. 4 is possible. Livy, interested exclusively in the narrative, passes over Polybius' digression without any acknowledgement. ${ }^{10}$ The same observation can be made at the

e.g. Riggsby 2006 on Caesar). The opportunity to raise these issues was missed by Schepens and Bollansée 2005 (for which see below).

\footnotetext{
8 Feyel 1942: 14 n. 1.

9 Livy 36. 5-6.

10 Though Livy 36. 6. 2 does closely echo Plb. 20. 4. 1.
} 
end of the passage, where the return to the narrative is awkwardly signalled by a каi rá $\rho$ (20. 7. 5), which, contrary to its normal sense, introduces neither an explanation nor an example. ${ }^{11}$ On the other hand, the passage contains at least two allusions to Boeotian events mentioned in other books. First there is the punishment inflicted by Fortune on Boeotia after 192, probably in 171 when the Boeotian Confederacy was dissolved by the Romans, $v \pi \epsilon \hat{\rho} \rho \hat{\omega} \nu \dot{\eta} \mu \epsilon \hat{i} s$

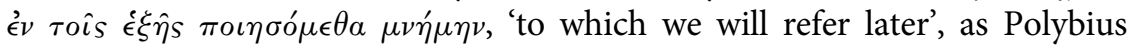
underlines at the end of the passage (20.7.2). Certainly Polybius is following an established plan in his writing of the History and knows without doubt in what order he is establishing his narrative. But one might also hypothesize that he has already written the section to which he refers in anticipation and is dipping into the rhetorician's toolbox so as to fix more firmly the digression into the narrative.

Secondly, Polybius places the argument found in Book 20 again in Book 22, stating that the Boeotian courts had stopped working for almost twenty-five years, $\sigma \chi \epsilon \delta \dot{\nu} \nu \epsilon^{\prime \prime} \kappa о \sigma \iota ~ \kappa a i ~ \pi \epsilon^{\prime} \nu \tau^{\prime} \dot{\epsilon} \tau \hat{\omega} \nu$ (20.6. 1 and 22.4.2), repeating verbatim his earlier text. Feyel, ${ }^{12}$ like all the commentators, is embarrassed by this repetition and thinks that the second instance was 'this time sincere', while giving little credit to the first. Independent from the content of this passage, it should be noted that Feyel's judgement is based largely on the fact that the second instance of the mention of the Boeotian law courts appears less artificial than the first. In other words, it is suggested that Polybius was merely repeating in the first instance his own argument with more emphasis.

\section{EXTERNAL CRITIQUE OR THE ANALYSIS OF THE HISTORICAL VALIDITY OF THE PASSAGE}

We now turn to consider the historical 'reality' of the decadence described by Polybius. Once we remove the diplomatic/military basis of the narrative, the concrete elements on which Polybius constructs his argument about Boeotian decadence are revealed to be few and far between. Polybius' main concern here is moral judgement and the only point on which any argument can rest is indeed the interruption to judicial life for twenty-five years. For this is

\footnotetext{
${ }^{11}$ Livy, almost certainly embarrassed by his source, wanted to present more continuity in his own account: after the Epirus episode, he runs on with some elegance, In Boeotiam ipse (Antiochus) profectus est (36. 6. 1) and sums up, in fairly brutal fashion, his discussion of Boeotian decadence, explaining it by the fact that re uera per multa iam saecula publice priuatimque labante egregia quondam disciplina gentis et multorum eo statu, qui diuturnus esse sine mutatione rerum non posset (36. 6. 2). This last sentence is, in fact, a variation on Polybius' own statement $\tau \hat{\eta} \delta^{\prime} a^{\lambda} \lambda \eta \theta \epsilon i$ a

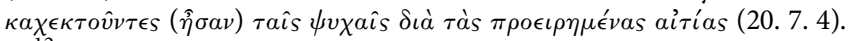

12 Feyel 1942: 275.
} 
seemingly one piece of precise information, potentially verifiable, on which Polybius stakes his claim.

We should remember that the return of this argument takes place in two passages whose dates of reference, or terminus ante quem, differ, one being 192 , the other 188. This difference therefore prevents any attempt at calculating precisely when the interruption took place. To give an example, Feyel and Walbank agree on the date of 188 as the point from which this retrospective judgement is made, and consider that the twenty-five-year period dates back to 213, counting back from the Peace of Apamea in 188. But the vague context in which this deceptively precise observation is offered by Polybius in Book 20 gives the impression that the whole century itself is concerned, as is the rhetorical aim of the author.

Whatever the starting date of the twenty-five years, we need to identify the breakdown in judicial life in order to verify Polybius' observation and so confront other contemporary sources, both literary and epigraphic. As Feyel has already pointed out, ${ }^{13}$ for the Hellenistic period we can turn to the lively, perhaps satirical, description of the Boeotian cities offered by Heraclides Criticus-or Creticus. ${ }^{14}$ In Heraclides' account, Thebes, and in particular judicial life there, functions with some difficulty and 'trials last more than

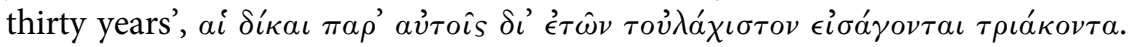
The mention of a precise length of time, and a rather similar one to that found in Polybius, demands some comparison of the two texts. The difficulty is that the Heraclides passage poses just as many problems as that of Polybius. Heraclides' description may appear to us to be first-hand impression and so to offer an effet de réel, but in fact it is in itself only an assemblage of clichés and sketches about the Boeotians. Nevertheless, it is thought that Polybius had been aware of Heraclides' description and indeed drew some inspiration from it, above and beyond any question of Glaubwürdigkeit, as G. A. Lehmann might say. ${ }^{15}$ However, as Walbank has shown, ${ }^{16}$ Heraclides' description concerns only Thebes, while Polybius' observation applies to the whole of Boeotia. In fact the information given by the two writers is not the same: for Heraclides, the thirty years applies to the trials themselves which drag on forever; while for Polybius it is the interruption in judicial activity which lasts for twenty-five years. In this case Polybius would have been severely misrepresenting his source, or at least have injected his own chronological calculation if he had been following Heraclides.

There is also a question about the date of authorship. The work of Heraclides is usually dated to the third century. Feyel raised some doubt about the

13 Feyel 1942: 275-6.

14 GGM, 258, §12-16. See Pfister 1951: 44 and, more recently, Arenz 2006.

15 Lehmann 1967.

16 Walbank, HCP iii. 72. 
date of Heraclides without being able to offer any precision apart from looking for difficulties in judicial procedure in Thebes. ${ }^{17}$ In other words, Polybius allows us to date Heraclides, who, in turn, confirms Polybius. Walbank was right to point out the circular nature of this argument, ${ }^{18}$ which leads us nowhere. A final possibility is that both Polybius and Heraclides shared a common source whom each interpreted in his own way. This, however, will not resolve the problem.

For the historian, the only way out of this literary dilemma is to consider Polybius alongside the epigraphical evidence. This is what Feyel attempted to do, but my own interpretation differs from his. ${ }^{19}$ Feyel seeks to show how Polybius' observation is valid from 220 and not 245: he wants to have his cake and eat it. For Feyel is unable to offer any Boeotian text that indicates the presence of foreign judges in the cities of the Boeotian Confederacy at the end of the third century. According to him, the presence of such judges would tend to suggest some kind of paralysis in the local courts. All the texts he offers come from parallel examples elsewhere, such as Delphi or cities in northern Greece. In fact, as Paul Roesch has demonstrated, no Boeotian decree honouring foreign judges can be found before the middle of the second century. After this point, at least six decrees are known. ${ }^{20}$ Elsewhere, foreign judges appear at the end of the third century or at the beginning of the second century. Is the situation in Boeotia peculiar to this region? Roesch argues that all the Boeotian decrees for foreign judges date from after the dissolution of the Boeotian Confederacy, in $171 \mathrm{BC}$, concluding that the institutional framework of the Confederacy ... provided all necessary jurisdiction' for the cities. ${ }^{21}$ After 171 the Confederacy ceased to exist and with its disappearance this juridical infrastructure was lost. At some point, to compensate for this loss, Boeotian cities began to turn to foreign judges. In sum, the catastrophic impression offered by Polybius is relevant neither to 245 nor to 220 , nor even to 192 nor 188 ! In fact, it may simply represent an interpretation, perhaps not a totally objective one, of the situation in Boeotia during the middle of the second century. The clearly anachronistic nature of the passage allows us to highlight an important contradiction: Polybius (20.7.1) has to concede that during the

\footnotetext{
17 Feyel 1942: 276. Feyel ends by suggesting 'une date voisine de 180' (n. 1), which means we cannot see how the period that Polybius has in mind can possibly be $213-188$.

${ }^{18}$ Walbank, HCP iii. 72: 'It may be noted that many attempts to date Heraclides use the conditions described in Polybius as a point of reference; hence the danger of circular argument.'

19 Feyel 1942: 276-7.

20 Roesch 1982: 407-11.

${ }^{21}$ Ibid. 407-8. Roesch offers seven examples from which we should in fact remove the two decrees of 'Thebes for the judges of Oropus' that were published later on the basis of the Roesch archives in 1993. Gauthier 1993 has demonstrated that these inscriptions not only belong to one inscription but are also part of an Eretrian decree honouring Oropian judges who have come to Thebes to rule on pending trials between the Boeotian and Euboean cities who are linked by a symbolon, i.e. a judicial agreement.
} 
difficult period of the reigns of Philip V and Antiochus III 'in spite of their constitution being in a deplorable state, and by I do not know what kind of fortune, the Boeotians avoided the catastrophes that came about at the time of

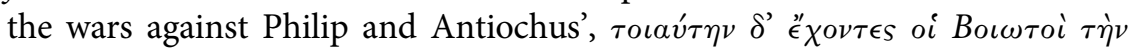

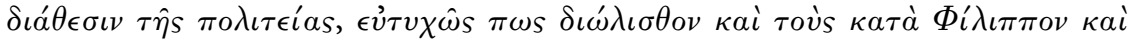

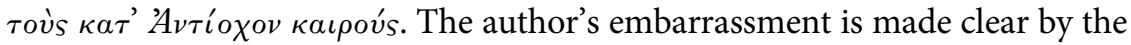
use of the particle $\pi \omega s$. This passage must therefore be understood in terms other than its description of a historical reality.

\section{POLYBIUS AND THE INTERTEXT}

I now change completely the tone of my paper in this, the third, section dealing with Polybius and intertext. I first explain what I understand by intertextuality and especially the way in which I am going to use this heuristic tool.

The concept of intertextuality has been revisited recently in relation to Polybius in a colloquium at Leuven published in 2005 as The Shadow of Polybius: Intertextuality as a Research Tool in Greek Historiography. ${ }^{22}$ In this volume, research into intertextuality is limited to those passages where the historian cites and evaluates his predecessors in a polemical framework. Here we are analysing the intertext by way of citation, and more precisely in what is called the 'cover-text method', the 'cover-text' being the receiving text, text B. Of course, this is hardly the first occasion on which intertextuality has been used to analyse ancient historiography. It is now around twenty years since this approach has entered the mainstream: we may think of Simon Hornblower's introduction to the 1994 volume Greek Historiography, ${ }^{23}$ in which the central issue is the reception of earlier authors of Greek history by later ones. ${ }^{24}$ Some may think that there was no need to wait for modern literary criticism to be interested in reception, and that intertextuality amounts to little more than jargon, in the same way that Monsieur Jourdain one day made the discovery that he was speaking in prose. But I do not hold to this view for, if no new theoretical techniques are applied to historiography, we can never be very far from the old form of source criticism which is always more interested in the text of origin rather than the receiving text, the receptor; this technique gives preference to text $\mathrm{A}$ rather than text $\mathrm{B}$, and considers the latter largely in terms

22 Schepens and Bollansée 2005.

${ }^{23}$ S. Hornblower 1994: 54-72, whose entire chapter is called 'Intertextuality and the Greek Historians'.

${ }^{24}$ See also Woodman 1988, where the emphasis on inuentio and literary conventions might also be felt to encourage intertextual approaches to set pieces like descriptions of the fall of a city and the like, or Laird 1999 for an interesting treatment of both intertextuality and historiography. 
of flaws in transmission. Intertextuality, on the other hand, offers us the chance of considering transformation, text $\mathrm{B}$ being no less creative than text A. In fact, we can consider intertextuality in a much more open way, as modern literary criticism has done since the term was defined by J. Kristeva in 1966 and in the light of subsequent developments. ${ }^{25}$ Of course, I think of G. Genette, ${ }^{26}$ whose 1982 work Palimpsestes has to a large extent served to codify our understanding of the concept and offered a 'Periodic Table' of all the categories that the concept covers going beyond a purely structural analysis of text.

To adopt this approach requires us to consider Polybius outside of his genre, outside of the historiographical status of the text, and to envisage the work as pure text, a difficult step for the historian but a useful one, especially if a historical sense is added to what might otherwise be purely formal. The aim here is, therefore, not to limit analysis to reception alone, or to external or vertical intertextuality, but to explore what some have termed 'intratextuality'. ${ }^{27}$ Intratextuality is not only the search for points of comparison, something that has been done for a long time. It plays more on the idea that the text, through repeating ideas, motifs, in linguistic terms 'isotopies', stops being referential (e.g. 'justice in Boeotia') but is itself self-generating. Intratextuality offers keys to the text that are no longer outside but found within. Kai gar... So let us return to Polybius and Boeotian decadence. The first appearance of $\kappa a \chi \epsilon \xi^{\prime} \alpha a$ among the Boeotians in Book 20 (20.4. 1) comes in its aberrant foreign policy. Polybius' vision of Boeotian foreign policy is one suggesting a permanent disaster. Victory at Leuctra (20.4. 2) was a kind of positive mistake, largely the result of the exceptional personality of its two leaders. ${ }^{28}$ This peak sits between two long troughs, periods of degradation that serve to echo each other in the narrative. Here one can see the first intervention of intertextuality, at once both internal and external. The 'Macedonianism' of the third century, if one can forgive the neologism, balances the Medism of the fifth century; Thebans in Polybius are only ever spoken of in terms of their betrayal. ${ }^{29}$ It is not Polybius' judgement that is interesting here, which is easy to deconstruct in historical terms, just as Eric Perrin has demonstrated concerning Polybius' judgement of Athens between 229 and $168 .^{30}$ Rather we have here the first motif in this embroidery of the Boeotians; here is the original sin that forms part of the historiographical inheritance, the cultural baggage of the second century, without there being a need to search

\footnotetext{
25 On the history of this idea, see the excellent introduction in Limat-Letellier 1998, esp. 18-19 and 36-46.

26 Genette 1982.

27 Limat-Letellier 1998: 26-7 and n. 18.

28 This point is seen at 20. 4, but is particularly evident earlier at 6. 43 .

29 For example, 4. 31 and 9. 39.

30 Perrin-Saminadayar 1999: 445-53.
} 
for direct allusions to predecessors. Polybius is incapable of interpreting Boeotian policy towards Macedonia without referring to this motif of betrayal. This motif produces the sense of the passage and imposes on the author his interpretation of the third century.

Therefore Polybius in Book 6 (6. 43) has a problem. For he does not know how to treat the Theban constitution. It should be remembered here that, even if it is not always the case, the Thebans in Polybius are often the Boeotians as a whole, and that it is difficult to say whether the Theban constitution is civic or federal, just as Epaminondas and Pelopidas are at the same time Thebans and Boeotians. The Boeotians are not alone in the difficulties their constitution presents to Polybius. Another constitution, the Athenian, is also dropped because it does not fit in with the criteria that Polybius has established for anacyclosis. When we fit the Boeotian constitution onto Polybius' scale, then it is identified as an ochlocracy without any hope of a way out. For Polybius himself says (6. 44. 9), 'it is useless to turn to the institutions of Athens and Thebes, cities in which the impulses of the mob drive everything. Each time that Polybius refers to the behaviour of the Boeotians, it is in these terms. This is a severe case of denying reality, since Polybius refuses to consider his subject (the Theban constitution). We see here how the disconnection between the text and the referent works.

Our second example of intertextuality: moral decadence produced by polit-

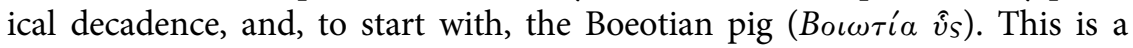
fascinating device, a motif that can be traced a long way back and that is reinserted into the Polybian construction. The 'Boeotian pig' is a linguistic isotopie that can be traced through Greek literature from Pindar through at least to Plutarch. ${ }^{31}$ It is in Pindar's sixth Olympian (1. 87-90) that we find the appearance of this idea that a Boeotian can be assimilated to a pig, a notion that Pindar already understands to be an ancient one. We then find the satirical traditions of Athenian comedy in the fifth and fourth centuries which crystallize the topos, as a passage from Alexis demonstrates. ${ }^{32}$ At the other end of this chronological chain, Plutarch ${ }^{33}$ refers to the Boeotians'

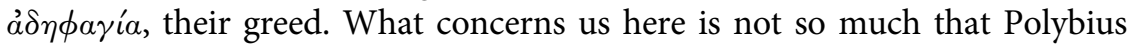
uses a motif typically voiced by the Athenians, whom he hates, but how this operation takes place. The original 'Boeotian pig' contains at least two representations, as outlined by Plutarch. One is of the crass ignoramus, the thick country-bumpkin, and the second is his pathological addiction to eating and drinking, $\epsilon \dot{v} \omega \chi^{\prime} a$ каi $\mu \epsilon^{\prime} \theta \eta$, an expression that Polybius uses twice in the

${ }^{31}$ For a nearly complete survey, see Guillon 1948, esp. 79-92, in an exasperated attempt to rehabilitate Boeotian values: nevertheless, one should remember his analysis of Heracles, the mythical hero who has become the target of much humour.

${ }_{32}$ Alexis F 239 K-A.

${ }^{33}$ Mor. 995e, De esu carnium. 
passage in Book 20. Polybius focuses in particular on the second aspect because he can insert it into his own paradigm: the association between drunkenness and moral decline, individual or collective, as already shown in Eckstein's work. ${ }^{34}$

This paradigm allows Polybius to show that the Boeotians are not the only Greeks to experience decadence. Among the most well-developed parallels, Walbank had already isolated two other examples of decline that are particularly significant: ${ }^{35}$ the savagery of the people of Cynaetha in Arcadia (4. 21. 2-12); and the o $\lambda_{\iota} \gamma \alpha \nu \theta \rho \omega \pi i^{\prime} a$ ('scarcity of people') affecting Greece (36. 17. $5-10)$. In the Cynaetha episode, supposed to be taking place in the 220s, the crucial word is 'savagery', ápı́ó $\eta$ s for the noun and better still the verb $\dot{a} \pi \circ \theta \eta \rho \iota^{\prime} \omega$ in the passive. This savagery leads us to two further points: the Boeotian pig, even if it is usually a domestic animal, represents bestiality, as do

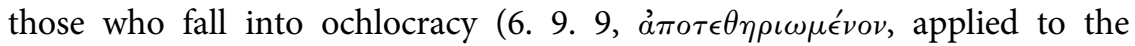
$\pi \lambda \hat{\eta} \theta o s)$. The process of $\dot{\alpha} \pi \circ \theta \eta \rho \iota^{\prime} \omega \sigma \iota s$ is a typical narrative motif that belongs to the paradigm of the barbarian. ${ }^{36}$ The Cynaethean story confirms, though in an inverted manner, the topos of the civilizing power of music. The reason why they have become so savage is, in contrast to the rest of the Arcadians, that they have not practised music, a cliché on the same scale as those that the Athenians created with regard to the Boeotians! It is also worth noting that the digression on the Cynaetheans is as badly inserted into the narrative as the passage on the Boeotians, thus showing its own particular status in the story: while the Cynaetheans are the victims of Aetolian brutality, it is the Cynaetheans who are presented as savage apparently because of an earlier episode.

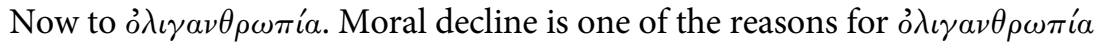
and this motif is played out differently depending on context. Boeotians who die childless drink away their wealth without leaving an inheritance to their agnate descendants (20.6. 5). In Book 36 (36. 17. 7), Polybius charges the Greeks with love of money ( marrying and from having children (from which results à $\pi a \iota \delta i a$, childlessness); instead, they prefer to spend their money elsewhere or to fritter away their patrimony. Here is a variation on the same theme that, like food and drink, leads us to the body. There would probably be much to say on this theme, in historical terms, echoing as it does Aristotle on the concentration of wealth in Sparta. But from a purely narrative perspective, we can see clearly how Boeotian decadence is woven with several threads.

Here the Romans enter the frame. They have clearly not been spared from moral decadence, as Polybius explains in Book 18 (18.35) and especially in

\footnotetext{
34 Eckstein 1995: 285-9.

35 In an article devoted to decline in Polybius, Walbank 1980.

36 For the links between the rule of the mob and barbarism, cf. Champion 2004a: 89.
} 
Book 31 (31. 25. 2-7), with the influx of wealth in Italy following the collapse of the Macedonian Kingdom. Polybius offers here a portrait of his friend Scipio, a eulogy that displays Scipio's virtue in the midst of widespread depravity. The social changes that take place between the end of the last Macedonian war and the destruction of Carthage are interpreted by Polybius, an eye-witness of the 'Roman crisis ${ }^{37}$ in terms that are essentially moral. From 'musical spectacles' to the abuse of banquets, via courtesans and demagogic practices, all strands come together to present Rome after 167 as a sort of paragon of decadence. Claude Nicolet, following Polybius' reasoning very closely, considered that, when he described demagogic practices at Rome, 'the impression corresponds too closely to the descriptions of extreme democracy in Polybius, for him not to have thought in particular of Greek states' ${ }^{38}$ However, it seems to me that the model, whether ideal or decadent but everywhere implicit, is that of Republican Rome. It is a model all the more immediate because the author makes it the object of his Histories and because he has been in part an eye-witness of it, while some of the examples of 'extreme democracy' in Greece date to the third century. It is tempting to see then that this scheme underlies the description that Polybius offers of Boeotian decadence in Book 20 and certainly other cases of Greek decadence. All the known ingredients of Roman decline are found in Boeotia: an ideal era-the Boeotia of Epaminondas - is followed by a miserable period in which political decadence, the demagogy of generals, interruption of judicial life doubles up with a perversion of customs, 'good food and drunkenness', mentioned on two occasions.

\section{CONCLUSION: POLYBIUS AND THE THEORY OF DECADENCE}

To conclude, three points. In terms of its composition, the passage from Book 20 on Boeotia shows all the signs of having been grafted a posteriori onto the central theme, at a date that obviously we cannot know, but which may be after 146. This is what the absence of internal logic, the external critique, and the analysis of the structural elements of the digression indicate. This suggestion conforms to what we know about how Polybius composed his work. As Pédech notes, after his return to Greece, Polybius was not happy to add a 'supplement to his earlier work; he revises it; he enriches it with additions'. ${ }^{39}$ Among those additions, some are only 'dated by a precise detail and identified

\footnotetext{
37 The term used by Pédech 1973.

38 Nicolet 1974: 214 n. $2 . \quad 39$ Pédech 1964: 563-4.
} 
distinctly by a remarkable unity'. It is very likely that with $20.4-7$ we have an example of this kind. The interruption of judicial life, even if Polybius gives his own version of it, is also much easier to understand if the situation to which he refers is that of the middle of the second century. Next, decadence. I have already mentioned the article in which Walbank suggested that, 'as the historian of Rome's rise to world power, Polybius was not particularly interested in the concept of decline'.$^{40}$ He followed this observation with a list of passages that refer to decline in Greece. This conclusion clearly owes much to optimism, the product of Walbank's sympathy for his subject. But in fact decadence is everywhere in the Histories. One can even see, as Craige Champion ${ }^{41}$ has shown, how Polybius drew an evolving curve of it, in Greece as in Rome, in spite of the fragmentary state of the books where its traces are the most obvious.

Finally, method. The analysis of the Polybian narrative, taken beyond the framework of its precise genre, allows us to reveal a number of motifs, often ancient and traversing the boundaries of previous works and from which the author draws to produce variations. So the Polybian intertext is not to be found only in the earlier historians, but in a range of texts, and even in representations and cultural codes that either precede him or are contemporary with him. Polybian narrative must therefore be studied as an object in itself, and not only as a marvellous referential canvas that allows us partially to fill the 'historiographic hole' that is the third century. In this sense I echo, albeit on a different plane, the analysis presented by Craige Champion, for whom Polybius is a fait culturel in himself, to use the term once employed by Claire Préaux. ${ }^{42}$ This type of analysis allows us to deconstruct the narrative, to avoid giving it too much credit. And it allows us to go further than a more straightforward study of Polybian prejudices. It allows us to show how the narrative is produced, by way of intratextuality, and what remains of it once one has patiently unwound the threads. This is where we see how the use of topoi nourishes the writing of history.

\footnotetext{
40 Walbank 1980: $41 . \quad 41$ Champion 2004a: 144-69.

42 Préaux 1978: i. 83: 'Polybe n'est pas seulement pour nous un historien. Il est un fait culturel en soi.'
} 